\title{
Cluster Analysis of Energy Diversification Patterns in Different Regions of China
}

\author{
Li Xiaodi,Sun Shipeng, Yang Xincai \\ Harbin Engineering University \\ Harbin, China \\ 958578783@qq.com
}

\begin{abstract}
Due to the diversity of fundamental situation among provinces in China, there are visibly regional differences in economic development level, resource endowments, and technological development level. For this reason, the energy diversification shows a big diversity on development model. This paper, based on 1991-2013 energy consumption structure data of 30 provinces and cities, applying cluster analysis method of panel data, classify the changing energy structure pattern among target provinces and cities, finally summarizes ten typical types of energy diversification patterns.
\end{abstract}

Keywords-energy structure; energy diversification pattern; cluster analysis

\section{INTRODUCTION}

China is a country covering vast territory; districts with different geography features, social economic and cultural environment shall form their unique pattern of energy diversification. In order to make a deep understanding of energy diversification patterns in different regions, we divide the energy consumption structure acquired from targets into groups by the method of cluster analysis.

At present, most cluster analysis is based on twodimensional cross-section data, relatively analysis referring 3D panel has less applications. Therefore, some scholars have developed the method and application of cluster analysis for 3D panel data. Yinguo $\mathrm{Li}$, Xiaoqun $\mathrm{He}(2010){ }^{[1]}$ took the panel data feature of panel and time series into consideration, constructed the distance function and Ward clustering algorithm for measuring similarity. Finally, they achieved clustering analysis on panel data, and had a good test from the application. Lifeng Wu, Sifeng Liu (2013) ${ }^{[2]}$ designed a panel data clustering analysis method to reflect the association degree of panel data by using the 3D grey convex relation degree, and found that this method was able to achieve a good clustering effect on the research objectives through actual test. Qunwei Wang, Shuangying Wang, Ze Cao (2014) ${ }^{[3]}$ applied the selforganizing competitive network algorithm to the cluster analysis of panel data, and obtained a good application effect through the test of actual cases.

On the basis of three methods of of cluster analysis of panel data mentioned above, after considering the need of research content, we select the panel data clustering method designed by Sifeng Liu and Lifeng Wu. The breakthrough point is that this paper, which adopts clustering analysis for panel data, makes a deeper research on the basis of the clustering analysis of cross-sectional data. The results obtained from the information contained in the panel data of urban energy consumption structure gets closer to the actual situation and provides an accurate and effective method and technical support for a better analysis of typical models and characteristics of energy diversification.

\section{Method of PANel Data Clustering For THREe- DIMENSIONAL GRAY CONVEXITY RELATION}

The method of panel data clustering based on 3D gray convex relation is as follows:

The first step is to transform the panel data waiting for clustering into the behavior matrix of the object.

The second step is to average the original data so as to remove the dimension effect of different indexes, so

$$
x_{i}^{\prime}(s, t)=\frac{x_{i}(s, t)}{\bar{x}(s, t)^{\prime}}, \quad \bar{x}(s, t)=\frac{1}{L} \sum_{1}^{L} x_{i}(s, t)
$$

The behavior matrix of the object $i$ is changed into

$$
X_{i}^{\prime}=\left[\begin{array}{cccc}
X_{i}^{\prime}(1,1) & x_{i}^{\prime}(1,2) & \cdots & x_{i}^{\prime}(1, n) \\
X_{i}^{\prime}(2,1) & \chi_{i}^{\prime}(2,2) & \cdots & X_{i}^{\prime}(2, n) \\
\vdots & \ddots & \vdots & \vdots \\
X_{i}^{\prime}(m, 1) & x_{i}^{\prime}(m, 2) & \cdots & \chi_{i}^{\prime}(m, n)
\end{array}\right] \text {, Where i }=1,2, \cdots, \mathrm{L} .
$$

The third step is to calculate the convexity of each point in the panel data, and then calculate the degree of correlation between any two objects, and compute an upper triangular correlation degree from the calculated association data, as shown in the following matrix:

$$
\left[\begin{array}{cccc}
\gamma_{11} & \gamma_{12} & \cdots & \gamma_{1 L} \\
& \gamma_{22} & \cdots & \gamma_{2 L} \\
& & \ddots & \vdots \\
& & & \gamma_{L L}
\end{array}\right]
$$

The fourth step is to set a reasonable threshold $r$ of correlation, according to the correlation matrix calculated in the 


\section{B ATLANTIS PRESS}

third step, and get the cluster analysis results of panel data. In practical applications, we take the appropriate critical value of correlation is generally 0.5 to 1 , that is $r \in[0.5,1]$.

When $\gamma_{i j}>r$, we think $i$ and $j$ are in the same cluster group, according to this method, traversing the correlation matrix, we get the final panel data clustering analysis results.

\section{PANEL DATA CLUSTER ANALYSIS RESULTS}

Because there isn't any cluster analysis application for panel data, we choose MATLAB and EXCEL to collate data and compute the data matrix, finally achieve empirical process and get results. According to the four steps mentioned above, we get the correlation matrix of clustering analysis for 30 provinces as shown in TABLE I. By setting different correlation critical value $r$, we assign values to $r$ as: $0.7,0.8,0.83,0.84,0.85,0.88$, then get the result which is greater than the critical value, finally get the clustering results as shown in Table II.

\section{TABLE I. TYPICAL ENERGY CONSUMPTION STRUCTURE OF PANEL DATA CLUSTER ANALYSIS}

RESULTS

\begin{tabular}{|c|c|c|c|c|c|c|c|c|c|c|c|c|c|c|c|c|c|c|c|c|c|c|c|c|c|c|c|c|c|c|}
\hline $\begin{array}{l}\text { Bei } \\
\text { Jing }\end{array}$ & $\begin{array}{l}\text { Tian } \\
\text { Jin }\end{array}$ & $\begin{array}{l}\text { Hei } \\
\text { Bei }\end{array}$ & $\begin{array}{l}\text { Shan } \\
\mathrm{Xi}\end{array}$ & $\begin{array}{l}\text { Neime } \\
\text { nggu }\end{array}$ & $\begin{array}{l}\text { Liao } \\
\text { Ning }\end{array}$ & Ji Lin & $\begin{array}{l}\text { Heilo } \\
\text { ngiian }\end{array}$ & $\begin{array}{l}\text { Shang } \\
\text { Hai }\end{array}$ & $\begin{array}{l}\text { Jiang } \\
\mathrm{Su}\end{array}$ & $\begin{array}{l}\text { Zhe } \\
\text { Jiang }\end{array}$ & $\begin{array}{l}\text { An } \\
\text { Hui }\end{array}$ & $\begin{array}{l}\text { Fu } \\
\text { Jian }\end{array}$ & $\begin{array}{l}\text { Jiang } \\
\mathrm{Xi}\end{array}$ & $\begin{array}{l}\text { Shan } \\
\text { Dong }\end{array}$ & $\begin{array}{l}\mathrm{He} \\
\mathrm{Nan}\end{array}$ & $\begin{array}{l}\mathrm{Hu} \\
\text { Bei }\end{array}$ & $\begin{array}{l}\mathrm{Hu} \\
\mathrm{Nan}\end{array}$ & $\begin{array}{l}\text { Guan } \\
\text { gDon }\end{array}$ & $\begin{array}{l}\text { Guan } \\
\mathrm{gXi}\end{array}$ & $\begin{array}{l}\text { Hai } \\
\text { Nan }\end{array}$ & $\begin{array}{l}\text { Chon } \\
\text { gQing }\end{array}$ & $\begin{array}{l}\text { SiChu } \\
\text { an }\end{array}$ & $\begin{array}{l}\text { Gui } \\
\text { Zhou }\end{array}$ & $\begin{array}{l}\text { YunN } \\
\text { an }\end{array}$ & $\begin{array}{l}\text { Shan } \\
\mathrm{Xi}\end{array}$ & $\begin{array}{l}\text { Gan } \\
\text { Su }\end{array}$ & $\begin{array}{l}\text { Qing } \\
\text { Hai }\end{array}$ & $\begin{array}{l}\text { Ning } \\
\text { Xia }\end{array}$ & $\begin{array}{l}\text { Xin } \\
\text { Jiang }\end{array}$ & \\
\hline & 0.71 & 0.67 & 0.66 & 0.66 & 0.71 & 0.69 & 0.67 & 0.72 & 0.67 & 0.67 & 0.66 & 0.65 & 0.66 & 0.68 & 0.65 & 0.67 & 0.65 & 0.7 & 0.64 & 0.49 & 0.66 & 0.64 & 0.66 & 0.65 & 0.7 & 0.72 & 0.68 & 0.66 & 0.65 & Bei jing \\
\hline & 1 & 0.73 & 0.71 & 0.71 & 0.81 & 0.76 & 0.78 & 0.8 & 0.74 & 0.74 & 0.71 & 0.7 & 0.71 & 0.75 & 0.73 & 0.72 & 0.69 & 0.79 & 0.69 & 0.45 & 0.69 & 0.66 & 0.72 & 0.73 & 0.78 & 0.81 & 0.66 & 0.73 & 0.65 & Tian jin \\
\hline & & 1 & 0.85 & 0.84 & 0.73 & 0.82 & 0.71 & 0.75 & 0.82 & 0.82 & 0.88 & 0.78 & 0.87 & 0.81 & 0.85 & 0.85 & 0.85 & 0.75 & 0.81 & 0.47 & 0.66 & 0.62 & 0.86 & 0.85 & 0.74 & 0.77 & 0.62 & 0.8 & 0.62 & Hebei \\
\hline & & & 1 & 0.9 & 0.72 & 0.79 & 0.7 & 0.75 & 0.81 & 0.82 & 0.87 & 0.76 & 0.83 & 0.78 & 0.79 & 0.83 & 0.81 & 0.76 & 0.8 & 0.47 & 0.67 & 0.62 & 0.88 & 0.84 & 0.74 & 0.76 & 0.61 & 0.77 & 0.61 & Shanxi \\
\hline & & & & 1 & 0.73 & 0.79 & 0.7 & 0.75 & 0.82 & 0.8 & 0.87 & 0.76 & 0.83 & 0.78 & 0.8 & 0.83 & 0.8 & 0.76 & 0.81 & 0.47 & 0.65 & 0.62 & 0.84 & 0.82 & 0.74 & 0.77 & 0.61 & 0.8 & 0.61 & Neimenggu \\
\hline & & & & & 1 & 0.77 & 0.79 & 0.77 & 0.76 & 0.75 & 0.73 & 0.71 & 0.72 & 0.76 & 0.75 & 0.73 & 0.71 & 0.77 & 0.69 & 0.45 & 0.7 & 0.68 & 0.74 & 0.74 & 0.76 & 0.8 & 0.66 & 0.73 & 0.67 & Liao ning \\
\hline & & & & & & 1 & 0.74 & 0.78 & 0.87 & 0.83 & 0.79 & 0.78 & 0.8 & 0.83 & 0.83 & 0.83 & 0.79 & 0.77 & 0.75 & 0.46 & 0.68 & 0.63 & 0.79 & 0.79 & 0.76 & 0.81 & 0.63 & 0.81 & 0.62 & Jilin \\
\hline & & & & & & & 1 & 0.74 & 0.75 & 0.74 & 0.7 & 0.7 & 0.7 & 0.74 & 0.71 & 0.71 & 0.69 & 0.74 & 0.67 & 0.45 & 0.73 & 0.67 & 0.71 & 0.7 & 0.76 & 0.77 & 0.63 & 0.71 & 0.66 & Heilongjiang \\
\hline & & & & & & & & 1 & 0.78 & 0.78 & 0.76 & 0.73 & 0.76 & 0.76 & 0.74 & 0.76 & 0.73 & 0.82 & 0.71 & 0.47 & 0.68 & 0.66 & 0.73 & 0.73 & 0.8 & 0.83 & 0.67 & 0.74 & 0.66 & Shanghai \\
\hline & & & & & & & & & 1 & 0.79 & 0.77 & 0.73 & 0.77 & 0.77 & 0.75 & 0.78 & 0.74 & 0.82 & 0.71 & 0.47 & 0.7 & 0.67 & 0.74 & 0.74 & 0.8 & 0.84 & 0.68 & 0.74 & 0.66 & Jiang su \\
\hline & & & & & & & & & & 1 & 0.83 & 0.83 & 0.84 & 0.83 & 0.78 & 0.84 & 0.82 & 0.83 & 0.78 & 0.47 & 0.71 & 0.65 & 0.78 & 0.78 & 0.78 & 0.79 & 0.63 & 0.8 & 0.63 & Zhe jiang \\
\hline & & & & & & & & & & & 1 & 0.78 & 0.88 & 0.8 & 0.81 & 0.87 & 0.87 & 0.77 & 0.83 & 0.46 & 0.65 & 0.62 & 0.84 & 0.82 & 0.75 & 0.76 & 0.61 & 0.8 & 0.61 & Anhui \\
\hline & & & & & & & & & & & & 1 & 0.8 & 0.79 & 0.76 & 0.78 & 0.79 & 0.78 & 0.8 & 0.45 & 0.66 & 0.61 & 0.74 & 0.74 & 0.73 & 0.74 & 0.61 & 0.77 & 0.61 & Fujian \\
\hline & & & & & & & & & & & & & 1 & 0.8 & 0.83 & 0.88 & 0.89 & 0.78 & 0.81 & 0.47 & 0.66 & 0.62 & 0.81 & 0.81 & 0.75 & 0.76 & 0.61 & 0.83 & 0.61 & Jiang xi \\
\hline & & & & & & & & & & & & & & 1 & 0.82 & 0.83 & 0.78 & 0.77 & 0.73 & 0.46 & 0.68 & 0.63 & 0.79 & 0.78 & 0.74 & 0.78 & 0.62 & 0.77 & 0.63 & Shan dong \\
\hline & & & & & & & & & & & & & & & 1 & 0.83 & 0.81 & 0.73 & 0.76 & 0.46 & 0.66 & 0.62 & 0.82 & 0.83 & 0.73 & 0.76 & 0.61 & 0.79 & 0.61 & Henan \\
\hline & & & & & & & & & & & & & & & & 1 & 0.75 & 0.7 & 0.7 & 0.6 & 0.64 & 0.63 & 0.7 & 0.71 & 0.69 & 0.7 & 0.63 & 0.73 & 0.63 & Hubei \\
\hline & & & & & & & & & & & & & & & & & 1 & 0.76 & 0.8 & 0.46 & 0.64 & 0.6 & 0.79 & 0.79 & 0.74 & 0.74 & 0.61 & 0.81 & 0.61 & Hunan \\
\hline & & & & & & & & & & & & & & & & & & 1 & 0.74 & 0.46 & 0.69 & 0.66 & 0.73 & 0.72 & 0.78 & 0.81 & 0.65 & 0.75 & 0.64 & Guangdong \\
\hline & & & & & & & & & & & & & & & & & & & 1 & 0.46 & 0.64 & 0.6 & 0.8 & 0.79 & 0.72 & 0.72 & 0.6 & 0.76 & 0.59 & Guangxi \\
\hline & & & & & & & & & & & & & & & & & & & & 1 & 0.47 & 0.47 & 0.46 & 0.46 & 0.48 & 0.46 & 0.45 & 0.46 & 0.47 & Hai nan \\
\hline & & & & & & & & & & & & & & & & & & & & & 1 & 0.75 & 0.67 & 0.66 & 0.71 & 0.7 & 0.64 & 0.65 & 0.71 & Chongqing \\
\hline & & & & & & & & & & & & & & & & & & & & & & 1 & 0.63 & 0.63 & 0.66 & 0.68 & 0.63 & 0.61 & 0.69 & Si chuan \\
\hline & & & & & & & & & & & & & & & & & & & & & & & 1 & 0.91 & 0.72 & 0.74 & 0.61 & 0.75 & 0.62 & Gui zhou \\
\hline & & & & & & & & & & & & & & & & & & & & & & & & 1 & 0.72 & 0.74 & 0.62 & 0.75 & 0.62 & Yun nan \\
\hline & & & & & & & & & & & & & & & & & & & & & & & & & 1 & 0.79 & 0.68 & 0.73 & 0.65 & Shanxi \\
\hline & & & & & & & & & & & & & & & & & & & & & & & & & & 1 & 0.66 & 0.76 & 0.64 & Gansu \\
\hline & & & & & & & & & & & & & & & & & & & & & & & & & & & 1 & 0.59 & 0.62 & Qing hai \\
\hline & & & & & & & & & & & & & & & & & & & & & & & & & & & & 1 & 0.6 & Ning $x i a$ \\
\hline & & & & & & & & & & & & & & & & & & & & & & & & & & & & & 1 & Xin jiang \\
\hline
\end{tabular}

TABLE II. PANEL DATA CLUSTER ANALYSIS GROUP RESULTS

\begin{tabular}{lc}
\hline Groups & Group members (province, city, district) \\
\hline Group One & Inner Mongolia, Shanxi, Guizhou and Yunnan \\
Group Two & Hubei, Hunan, Anhui, Jiangxi, Hebei, Henan, \\
& Ningxia \\
Group Three & Jilin, Shandong, Shaanxi, Jiangsu, Zhejiang \\
Group Four & Heilongjiang, Liaoning, Tianjin, Gansu, Shanghai, \\
& Guangdong \\
Group Five & Fujian, Guangxi \\
Group Six & Sichuan, Chongqing \\
Group Seven & Beijing \\
Group Eight & Qinghai \\
Group Nine & Xinjiang \\
Group Ten & Hainan \\
\hline
\end{tabular}

The first group of energy diversification patterns is clustered in the southwest and the north; the second group of energy diversification patterns is clustered in the central region; the third group of energy diversification patterns is clustered in one province in northeast China, three provinces in East China and one province in Northwest China. The fourth group of energy diversification patterns is located in two provinces in northeast, one in northwest and one in southeast. The fifth group of energy diversification patterns is distributed in South China and the sixth group of energy diversification patterns is clustered in the southwestern provinces. The seventh group of energy diversification patterns is only in Beijing. The eighth type of energy diversification patterns is Qinghai model. The ninth type of energy diversification patterns is Xinjiang model. The tenth 
energy diversification patterns are Hainan model. It can be seen from the spatial distribution that groups have a strong correlation in geographical locations, a phenomenon that should be related to that similar energy resources exist in the relevant area, so members of one group have a similar resource endowment and show a similar pattern of energy diversification. Of course, the factors that affect the diversification of energy resources are far more than resource endowment; other factors such as technology, environment, society, population also make significant impact.

\section{COMPARATIVE ANALYSIS OF TYPICAL ENERGY DIVERSIFICATION PATTERNS}

According to the cluster analysis results of the above table, the thirty sample provinces and cities in this paper are divided into ten different groups. Based on the analysis of the characteristics and changes of each group data, ten typical energy diversification mode and characteristics are summarized.

Firstly, we make definition of six small concepts. Proportion between $80 \%$ to $100 \%$ is called a Absolutely Dominant(AD), between $65 \%$ and $80 \%$ called it Strong Dominant(SD), $50 \%$ to $65 \%$ called Weakly Dominated(WD), $30 \%$ to $50 \%$ is called Absolute Added(AA), $15 \%$ to $30 \%$ as Strong Complement(SC), added $0 \%$ to $15 \%$ as Weakly Complement(WC).

TABLE III. CHARACTERISTICS OF TEN TYPICAL MODELS OF ENERGY DIVERSIFICATION

\begin{tabular}{|c|c|c|}
\hline Category & Consumption ratio & $\begin{array}{c}\text { Group } \\
\text { characteristics }\end{array}$ \\
\hline $\begin{array}{l}\text { The first } \\
\text { category }\end{array}$ & $\begin{array}{l}\text { Coal: } 85 \%-95 \% \text {; } \\
\text { Oil, Natural gas: close to } 0 \% \text {; } \\
\text { Electricity: close to but less than } 10 \%\end{array}$ & Coal AD \\
\hline $\begin{array}{l}\text { The second } \\
\text { category }\end{array}$ & $\begin{array}{l}\text { Coal: } 70 \%-80 \% \text {; } \\
\text { Electricity: close to but higher than } 10 \% \text {; } \\
\text { Crude oil: close to but less than } 10 \% \text {; } \\
\text { Natural gas : gradually increased from } 0 \% \text { to } 2 \%-4 \%\end{array}$ & $\begin{array}{l}\text { Coal SD } \\
\text { Crude oil WC } \\
\text { Electricity WC }\end{array}$ \\
\hline $\begin{array}{l}\text { The third } \\
\text { category }\end{array}$ & $\begin{array}{l}\text { Coal }: 60 \%-70 \% \\
\text { Crude oil: close to } 20 \% \\
\text { Electricity: close to } 10 \% \\
\text { Gas: } 0 \% \text { gradually increased to } 2 \%-5 \%\end{array}$ & $\begin{array}{l}\text { Coal SD } \\
\text { Crude oil SC } \\
\text { Electricity WC }\end{array}$ \\
\hline $\begin{array}{l}\text { The fourth } \\
\text { category }\end{array}$ & $\begin{array}{l}\text { Coal : } 50 \%-60 \% \\
\text { Crude oil: about } 30 \% \text {; } \\
\text { Electricity: increased to } 10 \%-15 \% \text {; } \\
\text { Natural gas :from } 0 \%-3 \% \text { to } 4 \%-9 \%\end{array}$ & $\begin{array}{l}\text { Coal WD } \\
\text { Crude oil SC } \\
\text { Electricity WC }\end{array}$ \\
\hline $\begin{array}{l}\text { The fifth } \\
\text { category }\end{array}$ & $\begin{array}{l}\text { Coal :from } 85 \%-90 \% \text { absolute lead into } 55 \%-60 \% \text { weak leading; } \\
\text { Crude oil :increased from single digits to } 15 \%-20 \% \text {; } \\
\text { Electricity :increased from just over } 10 \% \text { to } 20 \%\end{array}$ & $\begin{array}{l}\text { Coal AD to WD } \\
\text { Crude oil WC } \\
\text { to SC } \\
\text { Electricity } \\
\text { WC to SC }\end{array}$ \\
\hline $\begin{array}{l}\text { The sixth } \\
\text { category }\end{array}$ & $\begin{array}{l}\text { Coal :from } 80 \%-85 \% \text { dominant to } 60 \%-70 \% \text { dominated; } \\
\text { Crude oil: remained close to } 0 \% \text {; } \\
\text { Natural gas and Electricity from slightly lower than nearly } 10 \% \\
\text { to } 15 \%-20 \% \text { and tend to } 20 \%\end{array}$ & $\begin{array}{l}\text { Coal AD to WD } \\
\text { Electricity } \\
\text { WC to SC }\end{array}$ \\
\hline $\begin{array}{c}\text { The seventh } \\
\text { category }\end{array}$ & $\begin{array}{l}\text { Coal: } 69 \% ; \text { Crude oil: } 33 \% \\
\text { Electricity: } 7 \% \text {; Natural gas : } 1 \% \\
\text { Gradually developed into a very balanced energy structure, the } \\
\text { consumption ratio of coal, crude oil, natural gas, electricity is } \\
\text { about } 20 \%\end{array}$ & $\begin{array}{l}\text { Coal AD to WD } \\
\text { Crude oil } \\
\text { AC to SC } \\
\text { Electricity } \\
\text { WC to SC }\end{array}$ \\
\hline $\begin{array}{l}\text { The eighth } \\
\text { category }\end{array}$ & $\begin{array}{l}\text { Coal : } 77 \% \text {, Crude oil }: 10 \% \text {, } \\
\text { Electricity: } 12 \% \text {, Natural gas :about } 1 \% \text {, } \\
\text { Gradually transformed into Coal:absolutely } 40 \% \text {, Crude oil: } 10 \% \\
\text { Natural gas :about } 20 \%, \\
\text { Electricity: about } 30 \%\end{array}$ & $\begin{array}{l}\text { Coal SD } \\
\text { to AC } \\
\text { Crude oil WC } \\
\text { Electricity } \\
\text { WC to SC }\end{array}$ \\
\hline $\begin{array}{l}\text { The ninth } \\
\text { category }\end{array}$ & $\begin{array}{l}\text { Coal : } 61 \% \text {, Crude oil : } 32 \% \text {, } \\
\text { Electricity and Natural gas: } 7 \% \\
\text { Gradually evolved into } \\
\text { Coal : } 50 \% \text {, Crude oil : } 20 \% \text {, } \\
\text { Electricity and Natural gas: about } 10 \% \text {. }\end{array}$ & $\begin{array}{l}\text { Coal WD } \\
\text { Crude oil SC } \\
\text { Electricity WC }\end{array}$ \\
\hline $\begin{array}{l}\text { The tenth } \\
\text { category }\end{array}$ & $\begin{array}{l}\text { Coal: } 74 \% ; \\
\text { Electricity: } 26 \% ; \\
\text { Crude oil and Natural gas :0\% } \\
\text { Gradually evolved into } \\
\text { Crude oil :about } 40 \% \\
\text { Coal and Natural gas:about } 25 \% \\
\text { Electricity: about } 10 \%\end{array}$ & $\begin{array}{l}\text { Coal SD } \\
\text { to SC } \\
\text { Crude oil } \\
\text { WC to AC } \\
\text { Electricity } \\
\text { SC to WC }\end{array}$ \\
\hline
\end{tabular}




\section{CONCLUSION}

In this paper, we cluster the energy diversification patterns of 30 provinces and cities by cluster analysis of time series data and panel data, and compare and analyze the characteristics of diversification patterns of different groups, and get some typical energy diversification models, which has a certain reference value for the development of various regions in our country and the energy diversification mode which adapts to its own conditions.

\section{ACKNOWLEDGMENT}

I would like to express my gratitude to all those who helped me during the writing of this paper. With the help of my supervisor Professor $\mathrm{Li}$, I have overcome difficulties. I do appreciate her patience, encouragement, and professional instruction. What's more, I want to thank my thesis advisor, who kindly gives me a hand during my paper writing. At last, comments and suggestions are most welcome.

\section{REFERENCES}

[1] Cingguo LI, Xiaoqun HE.Cluster Data Clustering Method and Its Application [J]. Statistical Research, 2010, 27(9): 75-81. In Chinese

[2] Lifeng WU, Sifeng LIU.Cluster Data Clustering Method Based on Gray Convexity Degree and Its Application [J] .Control and Decision, 2013, 28 (7): 1032-1036, 1045. In Chinese

[3] Shuangying WANG, Qunwei WANG, Ze CAO.Multi - index Panel Data Clustering Method and Its Application - Taking Industry Primary Energy Consumption Panel Data as an Example [J].Mathematical Statistics and Management, 2014, 33 (1): 42-49. In Chinese

[4] Xianguo Li. Diversification and localization of energy systems for sustainable development and energy security[J]. Energy Policy, 2005, (33): 2237-2243. In Chinese

[5] Lior N. Sustainable Energy Development: the Present (2011) Situation and Possible Paths to the Future[J]. Energy, 2012, 43(1): 174-191.

[6] Stirling Andy. A general framework for analysing diversity in science, technology and society[J]. Journal of the Royal Society Interface, 2007, 4(15): 707-719. 